\title{
Can Indonesia Cocoa Farmers Get Benefit on Global Value Chain Inclusion? A Literature Review
}

\author{
Irfan Nabhani ${ }^{1}$, Arief Daryanto ${ }^{1}$, Machfud Yassin ${ }^{1} \&$ Amzul Rifin ${ }^{1}$ \\ ${ }^{1}$ Graduate School of Management and Business, Bogor Agricultural University, Indonesia \\ Correspondence: Irfan Nabhani, Graduate School of Management and Business, Bogor Agricultural University, \\ Jl. Padjajaran, Bogor, Indonesia. Tel: 62-81-680-0466. E-mail: irfan@nabhani.org
}

Received: March 23, 2015 Accepted: April 11, 2015 Online Published: June 5, 2015

doi:10.5539/ass.v11n18p288 URL: http://dx.doi.org/10.5539/ass.v11n18p288

\begin{abstract}
The purpose of this paper is to analyze the potential benefit of Indonesia cocoa farmers in the global value chain inclusion. The fact that there is a gap between international price and farmer's price is due to existence of power asymmetry especially on supply side. This paper uses global value chain perspective and the existence of internet innovation in food supply chain network by reducing the power asymmetry with a benchmark from developed and emerging market. We recommend some issues need to be intervened and resolved by the government, before the farmers could benefit on global value chain inclusion by internet adoption. On the other hand, telecommunication infrastructure deployment and increasing internet penetration are the necessity, and education on benefit of ICT inclusion in daily operation is becoming the next step. This conclusion supports the role of ICT in agriculture which is providing access to the market, financial inclusion, and access to technology.
\end{abstract}

Keywords: Indonesia cocoa farmers, cocoa global value chain, competitiveness, internet adoption

\section{Introduction}

In Indonesia, cocoa is the 3rd seed export commodities after palm oil and rubber. According toMinistry of Economic Affairs Republic of Indonesia (2011) Indonesia istop 2 cocoa producers which a contribution of 18\% in the global market, while according to ICCO (2013) Indonesia is the top three world producers after Cote d'Ivoire and Ghana. In national level, cocoa also earn the third largest export commodity after palm oil and rubber. The cocoa export trading in 2009 reached USD 1.38 billion (derived from cocoa beans and processed). Demand for cocoa beans for America and Europe reached 2.5 million tons per year (MoEARoI, 2011).

Most of cocoa producers are developing countries while the final product manufacturers are based in developed counties such as USA, Europe, and Japan as shown in the Table 1 and Table 2.

Table 1. World producer countries of cocoa beans (ICCO, 2014)

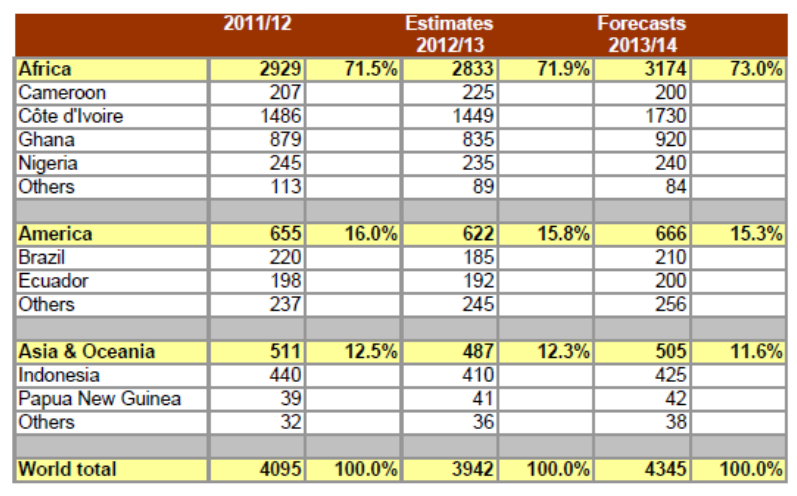

Based on interview by KPPU (2009) to Government Agency, Association of Indonesia Cocoa, Association of Indonesia Cocoa Farmers, and academics, the top seven problems in Indonesia cocoa are:

(1) Processing industries have difficulties finding fermented cocoa. 
(2) Low productivity and quality of Indonesia cocoa plants.

(3) Cocoa pest and disease

(4) Lack of financial support to the farmers

(5) Too many intermediaries in the cocoa trading chain

(6) Importers demand for non-fermented cocoa

(7) Increasing demand on export of cocoa

Table 2. Top ten chocolate producers (ICCO, 2014)

\begin{tabular}{|l|c|}
\hline Company & Net Sales 2013 (US\$ millions) \\
\hline Mars Inc (USA) & 17,640 \\
\hline Mondelēz International Inc (USA) & 14,862 \\
\hline Nestlé SA (Switzerland) & 11,760 \\
\hline Meiji Holdings Co Ltd (Japan) & $11,742^{*}$ \\
\hline Ferrero Group (ltaly) & 10,900 \\
\hline Hershey Foods Corp (USA) & 7,043 \\
\hline Arcor (Argentina) & 3,700 \\
\hline Chocoladenfabriken Lindt \& Sprüngli AG (Switzerland) & 3,149 \\
\hline Ezaki Glico Co Ltd (Japan) & $3,018^{*}$ \\
\hline Yildiz Holding (Turkey) & 2,500 \\
\hline
\end{tabular}

Research by Rifin (2013) using Revealed Comparative Advantage (RCA) and Almost Ideal Demand System (AIDS) tools, Indonesia has a comparative advantage on producing cocoa beans although it is still below Ivory Coast, Ghana, and Nigeria. This research also concludes that Indonesia and Ghana's cocoa beans are complementary in the international market and recommends cooperation between two countries to get the most benefit on the increase of world demand.

\section{Global Value Chain}

A value chain is the full range of activities that firms and workers do to bring a product or service from its conception to its end use and beyond. The activities that are included in a value chain are design, production, marketing, distribution and service/support to the end user. All the activities in a value chain can be done by a single firm or divided among a number of firms. They can be contained within a single geographical location or spread over wider geographic regions/countries. When the chain of interrelated activities to bring out a product or service from concept to complete production and delivery to final consumers is divided among multiple firms in different geographic locations, it is known as the Global Value Chain (CTCS, 2013).

Through the globalization, the majority of developing countries, including the poorest, are increasingly participating in GVCs. GVC links in developing countries can play an important role in economic growth, domestic value added created from GVC trade can be very significant relative to the size of local economies. The developing country share in global value added trade increased from $20 \%$ in 1990 to $30 \%$ in 2000 to over $40 \%$ in 2010s. (UNCTAD, 2013).

Global Value Chain gives us an understanding on the nature of interaction between demand side and supply side in a specific sector and provides the analysis tool in developing intervention to include small farmers in the value chain (Zylberberg, 2013). We will use GVC perspective in identifying the opportunities for cocoa farmers to move up their value chain by producing a higher value of product and processes as well as an effective tool for farmer empowerment. (-40)

\section{Indonesia Cocoa Value Chain}

Cocoa industry plays an important role in the Indonesia economy growth, it creates revenue sources, trading commodity, development of agro-industry, and the creation of employment opportunities. Government believes that they should revitalize and develop this sector include investment in the cocoa base, upstream-downstream supply, and infrastructure to support this role (MoEARoI, 2011).

Final Report on Cocoa Cluster Performance Appraisal by SEADI (2012), an USAID project in West Sulawesi and South Sulawesi, provide a simple trading chain of cocoa in Sulawesi. Small farmers sells their product to the 
traders, bigger farmers sell directly to district wholesaler, traders bring the products to the larger merchant and finally wholesaler sell the product to the exporters.

Indonesia cocoa supply chain consist of farmers, cocoa collector, local traders, exporters, multi-national, and both local processors and manufacturers. (Syahrudin, 2012), There are three types of farmers based on the cocoa plantation ownership which are farmers as owners, sharecroppers and farm managers. Collectors take role of butting and cocoa beans collecting, usually they have financial capability to buy it in upfront, they take advantage on limited capability of the farmers in term of logistic. Traders will act as the marketing point for the exporters, local processors and MNC processors.

Panlibuton (2004) in the report on Indonesia Cocoa Value Chain Assessment identify the following stakeholders as part of cocoa value chain:

(1) Research/Extension conducted by government institution, research agency and private research

(2) Input Supply provides the basic and supporting material to the farmers (i.e. seed and planting material/tools, fertilizers, and pesticides)

(3) Growing process by smallholder farmers and large estates

(4) Collecting/Bulking by local collectors and buying station

(5) Trading process from collectors or directly from the farmers in some cases and sends the beans to the main cities.

(6) Local Processing of dried beans into a variety of processed cocoa products (i.e. cocoa paste or liquor, cake, powder, and butter).

(7) Local Manufacturing of producing final finished chocolate products.

(8) Exporting beans from collectors and traders then sell it to regional buyers.

(9) Importing/Trading, international agents primarily based in commodity market as the sources for large multinational processors and manufactures.

(10) Regional/International Processing, affiliation/subsidiary of some multinational processors which directly supply beans and product to them.

(11) International Manufacturing producers of final chocolate product mostly in well developed countries.

All of the previous studies on Indonesia cocoa value chain implied that the Indonesia cocoa farmers are part of the global cocoa value chain which most of the cocoa beans are manufactured by the more well-developed countries before send the final chocolate product to the global consumers. The chart in Figure 1 shows the gap of $15 \%-25 \%$ between farmer level and international market on the price of cocoa beans.

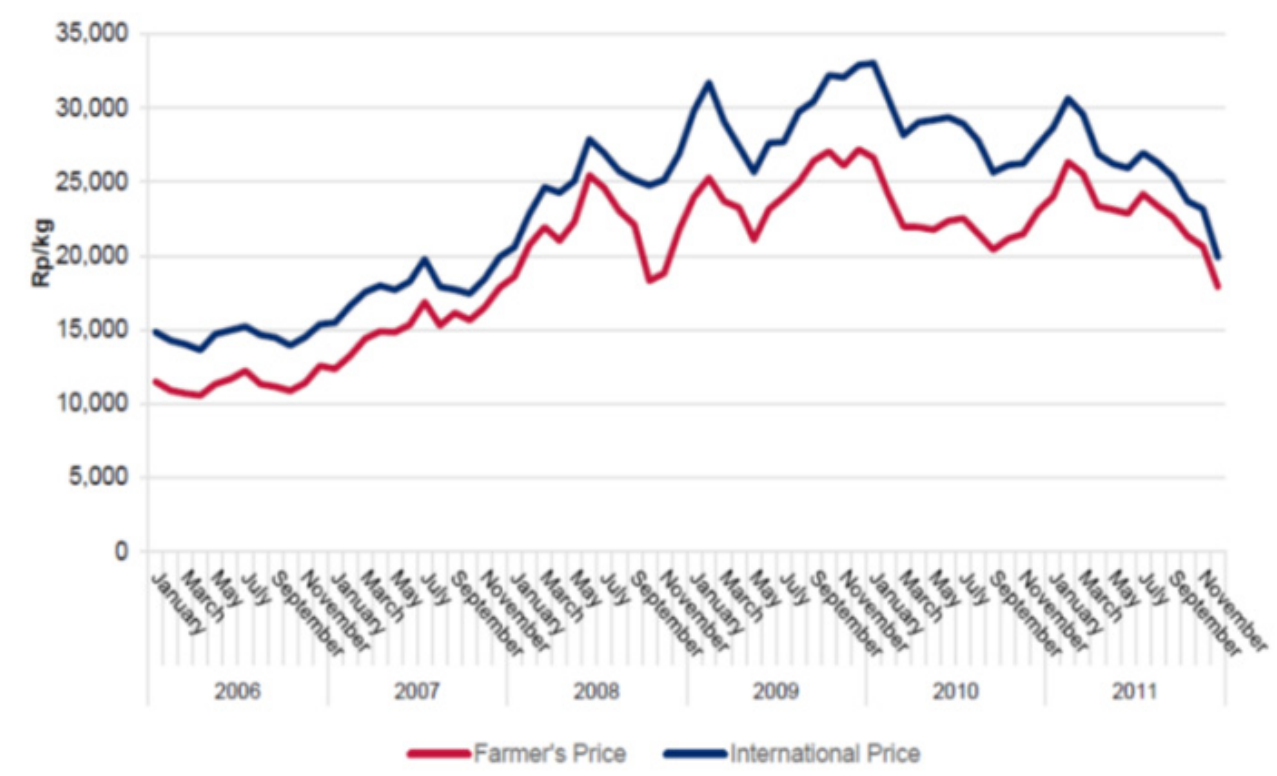

Figure 1. Price comparison between international and farmer of dried cocoa beans (Rifin, 2013) 


\section{Governance in Global Value Chain}

Gereffi et al. (1994) divided the value chain governance into producer-driven chains which the barrier to entry is capital and proprietary knowledge due to existence of high technology; and buyer-driven chains in which key barrier to entry is marketing costs, product design and market information, found in labor-intensive sectors.

Sturgeon et al. (2001) used the degree of standardization of product and process as a basis to divide the supply relationship into three types of (1) commodity suppliers, depend on generalized assets and often produce standard products, do not connect directly to the customers, price is the key factor, and suppliers could switch easily; (2) captive suppliers, depend on dedicated assets, high connectivity with customers and tend to be found within symbiotic supplier networks; and (3) turn-key suppliers, relatively independent stance toward their customers, high level of competence, ability to serve many type of customers and/or businesses.

Gereffi et al. (2005) uses three key determinants of value chain patterns: complexity of transaction, the ability to codify information, and capability of supplier. Based on those variables, Gereffi et al. (2005) defines five types of value chain governance structures:

(1) Market, involve transaction that are relatively simple, typical spot market; repeated transaction and low switching cost for both parties

(2) Modular, made by order to customer's specification, use generic machinery that limits transaction-specific investment, and make capital outlays for components and materials on behalf of customers.

(3) Relational, exist when buyers and sellers rely on complex information which create mutual dependence and high level of asset specificity, such linkages require trust and generate mutual reliance regulated through reputation, social and spatial proximity, and family and ethnic ties.

(4) Captive, small suppliers are transactionally dependent on much larger buyers and faces significant switching cost (captive). Such network are frequently characterized by a high degree of monitoring and control by lead firm

(5) Hierarchy characterized by vertical integration and dominated by managerial control such as headquarters to subsidiaries and affiliates.

He also identifies some dynamics of global value chain governance (Gereffi, 2011)such as: (1) shifting from market governance to relational by increasing complexity of transactions and reduces supplier competence in relation to new demands, (2) shifting from relational governance to market by reduce the complexity of transactions and greater ease of codification, (3) better codification of transactions to shift from relational to modular, (4) and the other way around by de-codification of transactions, (5) increasing supplier competence to shift from captive to modular, and (6) the other way around by decreasing supplier competence.

Table 3. Dynamics in global value chain governance (Gereffi, 2011)

\begin{tabular}{|c|c|c|c|}
\hline Governance type & Complexity of transactions & Ability to codify transactions & Capabilities in the supply-base \\
\hline Market & Low & High & High \\
\hline Modular & High & High & A High \\
\hline Relational & High & Low & High \\
\hline Captive & High & High & Low \\
\hline Hierarchy & High & Low & Low \\
\hline
\end{tabular}

With reference to Indonesia cocoa value chain, all the five archetypes of governance in global value chain are exist in Indonesia cocoa value chain as well as opportunities to upgrade the linkage and benefit according to the dynamics in global value chain governance.

\section{Potential Upgrading in the Dynamic of Global Value Chain Governance}

Kaplinsky (2000) uses GVC framework to understand that inequality has expanded markedly in spite of increasing integration of developing countries into the world economy due to these issues of governance and power symmetry; and Humphrey et al. (2010) states that smallholders are generally at a disadvantage when participating in GVCs for a multitude of reasons such as lack information about market opportunities and technology and they generally work through intermediaries and see marginal benefits from inclusion into value chains and not part of high value activities concentrated in developed countries. In his conclusion, he states that to grab the potential gains for the farmers, the governance of the chain need to be change due to very fragmented production of small farmers and the varied of intermediaries quality in agricultural market. 
As smallholders tend to participate in buyer-driven value chains, the power asymmetries present in these trading relationships hamper possibilities for upgrading into higher value-added activities (Zylberberg, 2013), and shifting from market governance to more relational reduced the power asymmetries substantially but pushed the intermediaries on supply side to produce more from their own farms rather than purchased from small farmers (Gereffi et al., 2005). Itneed an innovative smallholder-based business model as a viable path out of poverty in countries with low labor costs, suitable climatic conditions and basic infrastructural capacities(Zylberberg, 2013).

\section{Potential Contribution from ICT Inclusion}

Could ICT inclusion contribute to address the smallholder's issues in global value chain participation?FAO (2013) define that the utilization of ICT in agribusiness could contribute in the areas such as access to a better technology on production system management, access to market, and access to financial institutions. Porter (2001) implies that the role of internet in the competition will reduce the competitive advantage by making information widely available; reducing the barrier to entry such as physical stores, sales force, and channel distribution; and creating virtual market for more buyers and sellers.

A combination of global value chain governance reference with internet innovation in food supply chain network provide an opportunity for the supply side (farmers) to get benefit on global value chain inclusion and internet adoption by lowering the degree of power asymmetry as can be seen in the Figure 3. Implicitly, we need to "commoditizing" a "generic" specification of product in "virtual" market.

Consequently, by providing product at basic level, the farmers will be located at the bottom of value chain. There are some evidences on the initiatives to move up farmers' position in Indonesia cocoa value chain; Ministry of Agriculture RoI released a specific regulation to push the sales of fermented cocoa in farmer's point starting 2016; AMARTA (Agribusiness Market and Support Activity) project in Indonesia provided training and supporting activities for cocoa farmers include development of fermented cocoa community; and CIP (Cocoa Innovation Project) which has plan to push ICT usage among cocoa farmers and the providing financial services access through mobile application.
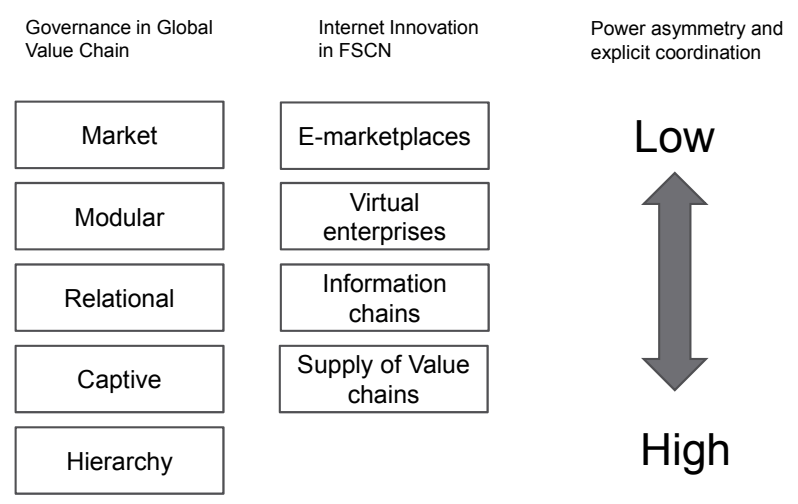

Figure 3. Combination of GVC Governance and Internet Innovation

(Gereffi, 2005 \& van der Vorst, 2005)

Even though there is a possibility of utilizing internet for beneficiary of farmers, there are some issues in ICT adoption by small holders, Stuart (2004) states that the success factor on information technology adoption by farmers in New Zealand is government projects related to the development of broadband infrastructure such as e-government and e-procurement. While Aleke et al. (2010) based on the results of research on the adoption of ICT from the perspective of a small -scale agribusiness in Nigeria stated that to ensure the success of the diffusion of an innovation, a balance must be maintained between the work done during the design of information and communication technology with social factors such as language and lifestyle. Sangha et al. (2010) which examines the role of ICT in the agriculture sector in India states that the barriers in adopting information and communication technologies by farmers are the lack of training, inadequate infrastructure, and equipment costs.

Taragola et al. (2004) compare the perception in the developed and developing countries of the ISHS symposium participants , the results stated that in developing countries there is no perception of the economic benefit, do not 
understand the value of benefits, and there is no time for information and communication technology . While in developed countries have already passed through an understanding of the benefits and time, but more emphasis on the need for the availability of infrastructure and technology costs.

Burke (2010) in his research on the adoption of information and communication technologies by small-scale agribusiness in Hawaii states that the growth of the size of the company and the increase of their operational complexity and structure will increase the role of information and planning, it needs to be supported by information technology and more advanced communication. Adamides et al. (2013) stated that almost $98 \%$ of farmers in Cyprus using the mobile phone as agricultural resources and advised the service provider to take advantage of this as dissemination tool for agricultural information.

Kumar (2012) based on the results of research on the use of information and communication technology for development of remote areas and agriculture in India concluded that the information and communications technology plays a very important role in the agricultural education, research and service development. Farmers will be made more intelligent and always be aided by the availability of digital information systems.

Ofusu-Asare (2011), his research in Ghana on the utilization of mobile phone by cocoa farmers concludes that the device is used to meet social and economic needs. It will include the arrangement for inputs, sales, information sharing, social media, and cost reduction especially on transportation..

\section{Conclusion}

Participation in cocoa global value chain does not automatically improve the cocoa small holders' quality of life, but there is a room for improvement by riding the dynamic of global value chain governance. Information and communication technology could help farmers to improve the level of complexity of transaction as well as increase farmers' ability to codify transaction by giving them access to (virtual) market and the latest technology and information about market needs.

Stuart (2004) state a widely broadband infrastructure is a necessity to create an ICT ecosystem for the farmer communities, and Sangha (2010) adds the importance of device penetration on the market. Aleke (2010) adds that the right application should be in place to complete the three pillars of ICT ecosystem. Broadband infrastructure deployment in farming area (rural) could face a profitability problem, decreasing trend of internet device price will automatically push the device penetration, and there are a lot of internet application in the market that provide the related info on technology (from cultivation to after-harvest processing) and last but not least is an adequate training to use it (Sangha, 2010) and induction of local context into the application (Aleke, 2010). Given the breadth of cocoa value chain, there is an opportunity for small farmer to shift their selling product to a more advance product along the value chain by adopting the proper technology. Government and business communities could help them in providing access to technology and financial services, while academics could help them in technology adoption process and the form of farmer association could strengthen their position in many aspects.

\section{References}

Adamides, G., \& Stylianou, A. (2013). ICT and Mobile Phone Use for Agricultural Knowledge Sharing by Cypriot farmers. Journal Agris on-line Papers in Economics and Informatics, 5(2), 3-10.

Aleke, B., Ojiako U., \& Wainwright D. W. (2011). ICT Adoption in developing countries: perspective from small-scale agribusiness. Journal of Enterprise Information Management, 24(1), 68-84. http://dx.doi.org/10.1108/17410391111097438

Burke, K. (2010). The Impact of Internet and ICT Use among SME Agribusiness Growers and Producers. Journal of Small Business and Entrepreneurship, 23(2), 173-194.

Canadian Trade Commissioner Service. (2013). Applying Global Value Chain: An Introduction for SME's.

Food and Agricultural Organization of the United Nations. (2013). ICT uses for inclusive agricultural value chains. Rome (IT).

Gereffi, G., Humprey, J., \& Sturgeon, T. (2005). The Governance of Global Value Chain. Review of International Political Economy, 12(1), 77-104. http://dx.doi.org/10.1080/09692290500049805

Gereffi, G. (2011). Global value chains and international competition. The Antitrust Bulletin, 1(56), 37-55.

Humprey, J., \& Navas-Aleman, L. (2010). Value chains, Donor intervention and Poverty Reduction: A Review of Donor Practice. IDS Research Report, 63.

Institute for Social and Political Economic Issues. (2012). Cocoa Cluster Performance Appraisal: Final Report. 
USAID-SEADI Discussion Paper No. 21.

Ministry of Economic Affair RoI. (2011). MasterPlan Acceleration and Expansion of Indonesia Economic Development 2011-2025.

Kaplinsky, R. (2000). Globalisation and unequalisation: What can be learned from value chain analysis. The Journal of Development Studies, 37(2), 117-146.

Kumar, J. (2012). Information and Communication Technology in Agriculture and Rural Development. Asia Pacific Journal of Management \& Entrepreneurship Research, 1(2), 193-209.

Ofusu-Asare, K. (2011). Mobile Phone Revolution in Ghana's Cocoa Industry. International Journal of Business and Social Science, 2(13), 91-99.

Panlibuton, H., \& Meyer, M. (2004). Value Chain Assessment: Indonesia Cocoa. USAID micro report \#2 on Accelerated Microenterprise Advancement Project (AMAP).

Rifin, A. (2013). Competitiveness of Indonesia's Cocoa Beans Export in the World Market. International Journal of Trade, Economics and Finance, 4(5), 279-281. http://dx.doi.org/10.7763/IJTEF.2013.V4.301

Rifin, A. (2013). Impact of Export Tax Policy on Cocoa Farmers and Supply Chain. USAID-SEADI Discussion Paper No. 1 .

Rifin, A., \& Nauly, D. (2013). The Effect of Export Tax on Indonesia's Cocoa Export Competitiveness. Proceeding paper for $57^{\text {th }}$ AARES Annual Conference, Sydney.

Sangha, A. S., \& Rakshit, S. K. (2010). Role of ICT in the Agriculture Sector: A Study of Progressive Farmers, Malwa Region, Punjab India. Proceeding of the AFITA 2010 International Conference.

Stuart, L. (2005). Farmer Adoption of ICT in New Zealand. The Business Review Cambridge, 3(2), 191-197.

Syahrudin, N., \& Kalchschmidt, M. (2011). Traceability in the Cocoa Supply Chain: An Indonesian Context. Retrieved from http://www.pomsmeetings.org/confproceedings/025/FullPapers/FullPaper_files/025-0129. pdf

Taragola, N., \& Gelb, E. (2004). Information and Communication Technology (ICT) Adoption in Horticulture: A Comparison to the EFITA Baseline. The 2004 ISHS Symposium. Berlin

UN Conference on Trade and Development. (2013). Global Value Chains and Development: Investment and Value Added Trade in the Global Economy. A preliminary analysis.

van der Vorst, J., Beulens, A., \& van Beek, P. (2005). Innovation in Logistics and ICT in Food Supply Chain Network. Innovation in Agri-Food System, 10, 245-292.

Zylberberg, E. (2013). Bloom or bust?A global value chain approach to smallholder flower production in Kenya. Journal of Agribusiness in Developing and Emerging Economies, 3(1), 4-26. http://dx.doi.org/10.1108/ 20440831311321638

\section{Copyrights}

Copyright for this article is retained by the author(s), with first publication rights granted to the journal.

This is an open-access article distributed under the terms and conditions of the Creative Commons Attribution license (http://creativecommons.org/licenses/by/3.0/). 